\title{
A Facile synthesis of ultra-small cerium oxide nanoparticles for enhanced Electrochemical Detection of Nitrobenzene in water samples
}

\author{
Arumugam Sangili, Muthaiah Annalakshmi, Shen-Ming Chen ${ }^{*}$, Tse-Wei Chen, Sakthivel Kumaravel, \\ Mani Govindasamy
}

Department of Chemical Engineering and Biotechnology, National Taipei University of Technology, Taiwan.

*E-mail: $\underline{\text { smchen78@ms15.hinet.net }}$

doi: $10.20964 / 2018.06 .118$

Received: 28 February 2018 / Accepted: 31 March 2018 / Published: 10 May 2018

The ultra-small cerium oxide nanoparticles $\left(\mathrm{CeO}_{2} \mathrm{NPs}\right)$ have been synthesized by the hydrothermal process. The structure and morphology of as-prepared nanoparticle were studied by transmission electron microscopy (TEM) and energy dispersive X-ray spectroscopy (EDX). The results confirm that the morphology of $\mathrm{CeO}_{2}$ NPs was obtained uniform and spherical structure with the size ranging from approximately $2-5 \mathrm{~nm}$. The obtained $\mathrm{CeO}_{2} \mathrm{NPs}$ was evaluated by the electrochemical sensing of nitrobenzene (NB). In order to, the sensor based on the modified SPCE exhibits good electrocatalytic activity and the sensitivity was about $1.1166 \mu \mathrm{A} \mu \mathrm{M}^{-1} \mathrm{~cm}^{-1}$. Remarkably, the $\mathrm{CeO}_{2} \mathrm{NPs}$ modified electrode showed the excellent lowest detection limit $0.092 \mu \mathrm{M}$ over the linear range from 0.1 to 520 $\mu \mathrm{M}$. Moreover, the ultra-small $\mathrm{CeO}_{2} \mathrm{NPs}$ was established good recoveries towards the determine the NB in tap water and river water samples.

Keywords: Cerium oxide; Hydrothermal; Nitrobenzene; Tap water; Mineral water.

\section{$\underline{\text { FULL TEXT }}$}

(C) 2018 The Authors. Published by ESG (www.electrochemsci.org). This article is an open access article distributed under the terms and conditions of the Creative Commons Attribution license (http://creativecommons.org/licenses/by/4.0/). 